\title{
Expanding the Pathways to Gender Equality in the Legal Profession
}

\author{
Hannah Brenner
}

\section{THE INEQUALITY OF WOMEN LAWYERS: A PROBLEM OF ETHICS}

The problem of gender inequality among lawyers has been a subject of recent and ongoing research, study and action. It is well known that despite women's entrance into law school in relatively equal numbers to men over the past few decades, they remain significantly under-represented in positions of leadership and power across sectors of the profession. ${ }^{1}$ In the top law firms in the United States, women account for only 17 per cent of law firms' equity partners (those who occupy the most prestigious, powerful positions, and who hold an ownership interest in their firm). ${ }^{2}$ This phenomenon is reflected across the globe. In Canada, available data suggests that while women have achieved parity in law school graduation rates, they account for only 26 per cent of lawyers in private practice, and ' $\mathrm{t}$ ] he percentage of women who are partners in law firms is even smaller. ${ }^{3}$ Discussing the position of women lawyers in Australia, Rosemary Hunter observes that

* Lecturer in Law and Co-Director, Frank J Kelley Institute of Ethics and the Legal Profession, Michigan State University College of Law, USA. Former Executive Director, Center for Women in Law, University of Texas School of Law. Special thanks to Hilary Sommerlad for her efforts in putting together this special issue. This essay would not have been possible without the exceptional research support of Kathleen Darcy. Emily Gillingham and Emily Jefferson also provided excellent research assistance in later stages of the work. All websites accessed August 2014.

1 'While some assert that the significant numbers of women in law school and in the profession commencing in the 1970s suggests that equality in the profession has been attained, a review of contemporary studies addressing sex discrimination in law and of recent litigation suggests otherwise.' Audrey Wolfson Latourette, 'Sex Discrimination in the Legal Profession: Historical and Contemporary Perspectives' (2005) 39 Valparaiso University Law Review 859.

2 National Association of Women Lawyers, Report of the Eighth Annual National Survey on the Retention and Promotion of Women in Law Firms (2014).

3 Alana Bassin and Lisa Ridgedale, 'Flight of Female Lawyers in Canada Mirrors US Exodus' (2009) 28(1) Of Counsel: The Legal Practice and Management Report, 7. 
$[\mathrm{w}]$ omen are clustered in the lower ranks of the professional hierarchy ... and at the lower levels of various sections of the profession, including the courts, law firms, and academia. Correspondingly, women lawyers earn lower incomes on average than their male counterparts. ${ }^{4}$

In addition to the global dearth of women in positions of leadership and power, as Hunter notes, there remains a significant salary disparity between male and female attorneys, particularly in the higher echelons of practice. ${ }^{5}$ The work of Ronit Dinovitzer and colleagues shows that '[a]mong a nationally representative cohort of lawyers who recently entered the profession, there is clear evidence of a continued gender gap in earnings. ${ }^{6}$ Of course, this phenomenon is not restricted to law. ${ }^{7}$ 'In most parts of the world, women are virtually absent from or are poorly represented in decision-making, including the formulation of financial, monetary, commercial and other economic policies, such as rules governing pay. ${ }^{8}$ Cynthia Fuchs Epstein identifies the sex division as ' $\mathrm{t}]$ he most persistent and arguably deepest divide in the world today. ${ }^{\text {? }}$

The research clearly reveals rampant gender inequality in the legal profession of a significant magnitude. The frame through which the issue is construed should shift toward conceptualising it as a matter of ethics. It is a problem that affects not just women, but the entire legal profession. What message does it send if the profession responsible for enforcing laws that challenge sexism and discrimination cannot itself figure out how to deal with the issue of equality amongst its own actors? Susan Sturm suggests how far-reaching such gendered dynamics might be: 'Patterns of exclusion are signals of more general institutional dysfunction. ${ }^{10}$ Is it ethical that the very profession charged with addressing such exclusion in other contexts lags behind in addressing its internal equality issues? While there is currently no mandate or rule requiring that the legal profession itself reflect gender equality among its own members, a profession that stands for and in fact enforces equality

4 Rosemary Hunter, 'Women in the Legal Profession: The Australian Profile' in Ulrike Schultz and Gisela Shaw (eds), Women in the World's Legal Professions (Hart Publishing, 2003) 87.

5 Martha Neil, 'Top In-House Lawyers Get Paid a Lot Less when Female, Survey Says' ABA Journal, 10 September 2013; Mary C Noonan, Mary E Corcoran and Paul N Courant, 'Pay Differences among the Highly Trained: Cohort Differences in the Sex Gap in Lawyers' Earnings' (2005) 84(2) Social Forces 851.

6 Ronit Dinovitzer, Nancy Reichman and Joyce Sterling, 'The Differential Valuation of Women's Work: A New Look at the Gender Gap in Lawyers' Incomes' (2009) 88(2) Social Forces 819, 843.

7 LaWanda Ward, 'Female Faculty in Male Dominated Fields: Law, Medicine and Engineering' (2008) 43 New Directions in Higher Education 63. Women scientists are on average paid 11\% less than their male counterparts. See Anastasia Prokos and Irene Padavic, 'An Examination of Competing Explanations for the Pay Gap among Scientists and Engineers' (2005) 19(4) Gender and Society 524. Among workers over the age of 16 in the United States in 2012, women earned only $80.9 \%$ of what men earned. Although women who worked as pharmacists (99.6\% of male pay) and secondary school teachers (93.1\%) were closer to pay parity, with women in some jobs exceeding male pay, other jobs like education administrators (67.2\%), marketing and sales managers (67.7\%), and personal financial advisors (66.3\%) lagged behind the average pay gap. US Bureau of Labor Statistics, 'Highlights of Women's Earnings in 2012' (2013) Report 1045, 11, 13, 17.

8 Anne-Marie Mooney Cotter, Gender Injustice: An International Comparative Analysis of Equality in Employment (Ashgate, 2004) 11.

9 Cynthia Fuchs Epstein, 'Great Divides: The Cultural, Cognitive, and Social Bases of the Global Subordination of Women’ (2007) 72 American Sociological Review 2.

10 Susan Sturm, 'From Gladiators to Problem-Solvers: Connecting Conversations about Women, the Academy, and the Legal Profession' (1997) 4 Duke Journal of Gender Law \& Policy 119. 
and rights should be emblematic of this idea. Indeed, as lawyers we should self-regulate to ensure that the profession is a model for others. Findings, like the one disclosed in the National Association of Women Lawyers' Report of the Eighth Annual National Survey on the Retention and Promotion of Women in Law Firms, which show that the position of women is not a universal goal among the nation's top firms, are unacceptable. ${ }^{11}$ In discussing moral activism as one of several approaches to legal ethics, Christine Parker writes: 'Moral activists argue that lawyers should use legal practice to change people, institutions and the law to make them conform better to general ideals of social and political justice. ${ }^{12}$

Framing the issue of gender inequality in a legal ethics context has received only limited attention. To give one example, Johnny Griggs argues, in the context of the problem of sexual harassment in firms, that ' $[\mathrm{b}]$ ecause the legal profession is regarded as the institution that advocates, protects, preserves and advances justice and fundamental fairness, law firms must be in the forefront of that quest. ${ }^{13}$ The importance of such representation was discussed generally by US Supreme Court Justice Ginsburg: 'Our system of justice is surely richer for the diversity of background and experiences of its judges. It was poorer when nearly all of its participants were cut from the same mold. ${ }^{14}$ Ensuring such diversity will require a profession-wide commitment. Wisconsin Supreme Court Justice Shirley Abrahamson remarked that ' $[\mathrm{a}]$ judiciary that includes substantial numbers of women and reflects the racial and ethnic diversity of the general population is essential to the public perception of justice as fair, impartial and representative. ${ }^{15}$ Justice Abrahamson's comment, while focused narrowly on the judiciary, can be extrapolated to the legal professional generally, and perhaps can even be taken a step further. The legal profession, as the gatekeeper of equality, may in fact be perceived as disingenuous or even unethical for not itself reflecting the kind of reality for which it stands. Does our failure to get this issue right ourselves weaken our efforts at enforcing equality? In his work exploring the field of legal ethics in the twenty-first century, Adam Dodek reflects, 'The issue of diversity within the profession is wide and deep, with serious ethical ramifications for the profession and the legal system. As with access to justice, it goes to the heart of the legitimacy of the legal profession and the legal system.' ${ }^{16}$

As one example of how gender inequality demands an ethical frame, consider the problem of sexual harassment. Sexual harassment was first defined by Catharine MacKinnon as '[t]he unwanted imposition of sexual requirements in the context of a

11 See National Association of Women Lawyers (n 2) 6.

12 Christine Parker, 'A Critical Morality for Lawyers: Four Approaches to Lawyers' Ethics' (2004) 30 Monash University Law Review 49, 66.

13 Johnny Darnell Griggs, 'Sexual Harassment in Law Firms: The Cobbler's Children Revisited' New Jersey Lawyer, the Magazine, August 2001.

14 Ruth Bader Ginsburg, 'Remarks on Women's Progress at the Bar and on the Bench' (2007) 30 Harvard Journal of Law \& Gender 1.

15 Shirley S Abrahamson, 'Do Women Judges Really Make a Difference? The American Experience' in Shimon Shetreet (ed), Women in Law (Kluwer, 1998) 200.

16 Adam M Dodek, 'Canadian Legal Ethics: Ready for the Twenty-First Century at Last' (2008) 48 Osgoode Hall Law Journal 42. 
relationship of unequal power. ${ }^{17}$ Today, it is a global problem of significant magnitude. ${ }^{18}$ There is a paucity of current data on the prevalence of sexual harassment specifically in the legal profession, though the available research suggests that it is a pervasive problem perpetuated by other lawyers, clients, and even judges. ${ }^{19}$ A 1995 report by the American Bar Association Commission on Women in the Profession revealed that over half of female attorneys had experienced sexual harassment. ${ }^{20}$ The American Bar Association's National Survey of Career Satisfaction/Dissatisfaction survey further revealed the prevalence of sexual harassment in the legal profession; nearly two-thirds of female lawyers in private practice and nearly half of those in corporate or public agency settings reported either experiencing or observing sexual harassment by male superiors, colleagues, or clients in the two years prior to the survey. ${ }^{21}$ It is not a problem limited to the law office, and the expansive nature of this problem makes it even more problematic as an issue of ethics. One report found that 15 per cent of all attorneys had witnessed a judge engage in sexual harassment with a female attorney, primarily taking the form of inappropriate sexual comments. ${ }^{22}$ A similar trend was noted in Minnesota, where 15 per cent of female attorneys reported that female litigants or witnesses were frequently sexually harassed verbally. ${ }^{23}$ And 47 per cent of female attorneys said that judges 'sometimes or often' made jokes that were demeaning to women, both in the courtroom and in chambers. ${ }^{24}$

One problematic dimension of this reality lies in the impact that sexual harassment has on the victims and their overall desire or ability to remain in the work environment. Female lawyers who had experienced or observed sexual harassment by male superiors or colleagues reported lower overall job satisfaction than those who had not, as well as a greater intention to quit. ${ }^{25}$ Fiona Kay and Joan Brockman note that in Canada ' $s$ s] exual

17 Catharine A MacKinnon, Sexual Harassment of Working Women (Yale University Press, 1979) 1.

18 In the United States, the Equal Employment Opportunity Commission documented 11,364 cases of sexual harassment reported in 2011; of this number, $84 \%$ of the cases were reported by women. See US Equal Employment Opportunity Commission, Sexual Harassment Charges: EEOC \& FEPAs Combined, www.eeoc. gov/eeoc/statistics/enforcement/sexual_harassment.cfm. While statistics can be difficult to obtain, the prevalence of sexual harassment is similar in international contexts. One study revealed that $11 \%$ of working Israeli women were sexually harassed at work in 2011, and a total of ' $[n]$ o less than 35 to $40 \%$ of Israeli women have experienced sexual harassment at work'. Haim Bior, 'A Third of Israeli Women Experience Sexual Harassment at Work', Haaretz (Israel), www.haaretz.com/print-edition/news/a-third-of-israeli-women-experience-sexualharassment-at-work-1.295009.

19 Peter Jan Honigsberg, Marilynn Tham and Gary Alexander, 'When the Client Harasses the Attorney: Recognizing Third Party Sexual Harassment in the Legal Profession (1994) 28 University of San Francisco Law Review 715.

20 American Bar Association Commission on Women in the Profession, Unfinished Business: Overcoming the Sisyphus Factor (1995), 18-19. Five years later, another version of this study revealed similar results, with between $50 \%$ and $65 \%$ of women lawyers having experienced sexual harassment. Ibid, 19.

21 David N Laband and Bernard F Lentz, 'The Effects of Sexual Harassment on Job Satisfaction, Earnings, and Turnover among Female Lawyers' (1998) 51 Industrial and Labor Relations Review 594.

22 Final Report of the Massachusetts Gender Bias Study, Gender Bias in Courthouse Interactions (1989), reprinted in part in (1989) 74 Massachusetts Law Review 50, 59.

23 Donna Shestowsky, 'Where is the Common Knowledge? Empirical Support for Requiring Expert Testimony in Sexual Harassment Trials' (1999) 51 Stanford Law Review 357.

24 Ibid.

25 See Laband and Lentz (n 21) 594. 
harassment has been documented as a significant obstacle to women's abilities to develop their careers in the practice of law. ${ }^{26}$ However, what is particularly difficult about the prevalence of incidences of sexual harassment in the legal system is that it is this system itself that is meant to protect citizens' rights and dispense justice. One attorney describes the dilemma thus: 'Given the stature, prestige and influence of law firms in our civil justice system, one would reasonably expect law firms to be in the vanguard in the battle to eliminate sexual harassment (and discrimination of all types) from the workplace.27

This essay begins from the premise that the existing gender inequality in the legal profession should be characterised as a problem of ethics, particularly against the backdrop that the progression of women lawyers has in fact stalled over the past few decades. Existing efforts at reform have yielded few tangible results. In this way, it is imperative that we continue to develop new theories and test new research hypotheses toward the end of creating a profession that embodies true equality. This essay reflects a number of my observations that may push this agenda forward. It seems that the existing discourse rarely expands beyond considering barriers unique to the traditional private practice setting or extends beyond the geographical borders of a particular country, and has overwhelmingly failed to consider legal education either as a source of the problem or as a site for crafting innovative solutions. Indeed, there is much to be learned looking around and outside of the law. Here, I seek to contribute new ideas, rethink old ones, and encourage further research in order to most effectively address the longstanding, pervasive, and stagnant problem of gender inequality in law.

\section{THE PROFESSION'S PROBLEMS DEFINED}

The problems facing women as they navigate the pipeline to power ${ }^{28}$ in the legal profession are sufficiently well documented today. ${ }^{29}$ The determination, drive and commitment exhibited by early pioneers in law clearly paved the way for women's entrance into the profession. No longer are women singularly represented in a sea of male lawyers. No longer are classes of law students merely, if at all, dotted with only the occasional female. Much to the contrary, the past two to three decades have been characterised by a pipeline to the legal profession filled with women. Women and men attend law school almost in equal numbers. ${ }^{30}$ They graduate and take jobs in all facets of the profession, from clerkships to

26 See Fiona Kay and Joan Brockman, 'Barriers to Gender Equality in the Canadian Legal Establishment' (2000) 8 Feminist Legal Studies 69.

27 Griggs (n 13).

28 Hannah Brenner and Renee Knake, 'Rethinking Gender Equality in the Legal Profession's Pipeline to Power: A Study on Media Coverage of Supreme Court Nominees (Phase 1, The Introduction Week)' (2010) 84 Temple Law Review 325.

29 See eg 'An Analysis of Work-Related Issues and Conditions of Lawyers in Western Australia' (2013), www. australianwomenlawyers.com.au/uploads/attachments/WLAWA_Survey_of_the_Profession_-FinalReport_7Oct13.pdf; Julie C Suk, 'Work-Family Conflict and the Pipeline to Power: Lessons From European Gender Quotas' [2012] Michigan Law Review 1797; Kay and Brockman (n 26).

30 American Bar Association Lawyer Demographics (2012), www.americanbar.org/content/dam/aba/migrated/ marketresearch/PublicDocuments/lawyer_demographics_2012_revised.authcheckdam.pdf. 
law firms to public interest to government to corporations. So, one might conclude, given the removal of formal barriers and obstacles, women have achieved the equality for which they once fought so hard. There are profound ways in which this is conclusion exactly right. That is, there are few, if any, positions in the profession that today are explicitly off limits to women. The early experiences of lawyers who were not hired simply because they were women are now only stories etched in the history of our profession. ${ }^{31}$ Women have broken the glass ceiling and are now running companies, heading law firms, running for major political office (including the Presidency), and serving as deans of law schools. ${ }^{32}$

Given this picture, there are many who believe that the equality 'dilemma' has been resolved since formal barriers to equality were eradicated decades ago, and women now have access to education and professional opportunities. They surmise that women 'have arrived' since they now have a presence in all areas of law. ${ }^{33}$ Others may admit that women have not necessarily burst through the glass ceiling in every realm of the legal profession, but they suggest that the problem is still likely to self-correct, that perhaps it is just a matter of time; in the 1980s and early 1990s many believed that since the pipeline was finally full of women (due largely to increased enrolment of female law students), true equality would eventually emerge. ${ }^{34}$ It was not long, however, before the soundness of this idea was seriously questioned. Across the globe, women lawyers began to reject the sentiment that simply waiting was likely to yield results. As an example of this skepticism, Justice Mary Gaudron called the soundness of the theory into question in a speech commemorating the opening of the Australian Women Lawyers association:

It has been said for many, many years that it is only a matter of time until women are properly represented in the various fields of legal endeavor. Well, how much time? It is close on 100 years since we've had women lawyers, since the doors have been formally open. Where has this progress got us? ${ }^{35}$

31 Virginia Drachman, Women Lawyers and the Origins of Professional Identity in America: The Letters of the Equity Club, 1887-1890 (University of Michigan Press, 1993).

32 White House Project, 'Benchmarking Women's Leadership', 73, www.eeoc.gov/federal/reports/women_ workgroup_report.cfm.

33 Maria Pabon Lopez, 'The Future of Women in the Legal Profession: Recognizing the Challenges Ahead by Reviewing Current Trends' (2006) 19 Hastings Women's Law Journal 53; Cynthia Fuchs Epstein, 'Women in the Legal Profession at the Turn of the Twenty-First Century: Assessing Glass Ceilings and Open Doors' (2001) 49 University of Kansas Law Review 733.

34 Nancy J Reichman and Joyce S Sterling, 'Sticky Floors, Broken Steps, and Concrete Ceilings in Legal Careers' (2004) 14 Texas Journal of Women and Law, citing Johnathan D Glater, 'Women are Closer to being Majority of Law Students' New York Times, 26 May 2001, A1; Rachel Davis and George Williams, 'A Century of Appointments but Only One Woman' (2003) 28 Alternative Law Journal 54; Georgina Murray, 'New Zealand Women Lawyers at the End of the Twentieth Century' in Ulrike Schultz and Gisela Shaw (eds), Women in the World's Legal Professions (Hart Publishing, 2003); speech to launch Australian Women Lawyers by the Honourable Justice Mary Gaudron, High Court of Australia, 19 September 1997; Kate Eastman, 'Sex Discrimination in the Legal Profession' (2004) 27 University of New South Wales Law Journal 872; Eli Wald, 'Glass Ceilings and Dead Ends: Professional Ideologies, Gender Stereotypes and the Future of Women Lawyers at Large Firms' (2010) 75 Fordham Law Review 2245.

35 Gaudron, ibid. 
Around the same time, American legal scholar Deborah Rhode famously labelled the denial that there is something wrong as the 'no-problem problem.' 36 'The no-problem problem prevents Americans from noticing that on every major measure of wealth, power and status, women still are significantly worse off than men. ${ }^{37}$ Her characterisation applies across borders as well. ${ }^{38}$ Although we have, perhaps, made significant strides to transcend the denial that Rhode described, there remains an elusive dynamic to gender inequality that makes it difficult to identify and ultimately correct. While many barriers have in fact been acknowledged, suggesting perhaps that we've moved beyond the 'no-problem problem', some still persist, and the solutions remain out of reach.

In some ways, today's inequality is reminiscent of the hidden 'problem' facing white, middle-class women in the 1960s that Betty Friedan so famously thrust into the mainstream. ${ }^{39}$ That is, these problems are often difficult to identify because they aren't always obvious. Although we have come close to reaching parity among male and female law students, ${ }^{40}$ some suggest that the number of women entering law school and the legal profession is actually declining. ${ }^{41}$ The public face of a law firm may also include the faces of women and minority attorneys, suggesting a balanced workforce; this phenomenon of tending to 'overestimate the proportion of a minority group present in a given population' has been characterised as 'visibility bias. ${ }^{42}$ Citing an example from her research on discrimination against female barristers in Australia, Hunter reveals how one solicitor estimated that between 20 and 30 per cent of the barristers he selected in his work were female, when the actual figure was closer to 10 per cent; in this context, the visibility bias resulted in solicitors believing they were giving women ample opportunities. ${ }^{43}$

The subtlety and related, resulting complexity associated with contemporary inequality has been described by retired Canadian Supreme Court Justice Claire L'Heureux-Dubé thus:

The idea of women on the bench may have gained acceptance since I was first appointed to the bench nearly 27 years ago, but the proper role for female jurists once they get there is still a work in progress. What we need is a change in attitudes, not simply a change in chromosomes. ${ }^{44}$

36 Deborah Rhode, Speaking of Sex: The Denial of Gender Equality (Harvard University Press, 1999) 1.

37 Ibid, 2.

38 Rachel Davis and George Williams, 'Reform of the Judicial Appointments Process: Gender and the Bench of the High Court of Australia' (forthcoming in Melbourne University Law Review); Barbara Hamilton, 'The Law Council of Australia Policy 2001 on the Process of Judicial Appointments: Any Good News for Future Female Judicial Appointees?' (2001) 1(2) Queensland University of Technology Law and Justice Journal 223.

39 Betty Friedan, The Feminine Mystique (WW Norton, 1964).

40 American Bar Association First Year and Total JD Enrollment by Gender 1947-2011, www.americanbar.org/ content/dam/aba/administrative/legal_education_and_admissions_to_the_bar/statistics/jd_enrollment_ 1yr_total_gender.authcheckdam.pdf.

41 Ann Farmer, 'Are Young Women Turning their Backs on Law School?' (2010) 18(4) American Bar Association Perspectives 1.

42 Rosemary Hunter, 'Discrimination against Women Barristers: Evidence from a Study of Court Appearances and Briefing Practices' (2005) 12(1) International Journal of the Legal Profession 15; Rosabeth Moss Kanter, Men and Women of the Corporation (Basic Books, 2nd edn 1983).

43 See Hunter (n 4) 15.

44 Claire L'Heureux-Dubé, 'Outsiders on the Bench: The Continuing Struggle for Equality' (2010) 16 Wisconsin Women's Law Journal 30. 
Implicit in her remarks is the identification and exposure of bias and stereotypes that have replaced the formal barriers to equality of the last century. Nancy Reichman and Joyce Sterling expound upon these ideas:

[W] omen continue to be systematically disadvantaged by patterns of behavior, often unconscious or taken for granted, where no one can be technically blamed. Explicit and implicit forms of gender discrimination as well as institutionalized processes and expectations that were designed with men in mind means that our expectations for gender equity do not necessarily translate into the choices and actions of gatekeepers to power, authority and resource control. ${ }^{45}$

Many of the barriers and obstacles that provide explanation for the inferior position of women in the legal profession have in fact been identified and researched; they include things like implicit gender bias, ${ }^{46}$ the maternal wall, ${ }^{47}$ double binds ${ }^{48}$ surrounding issues of sexuality, motherhood and marital status, inflexible workplaces, ${ }^{49}$ a paucity of effective mentors, ${ }^{50}$ and limited access to and failure to receive credit for important work assignments. ${ }^{51}$ The work that has been done in these realms is critical. Yet, the conversation to date often equates law practice with large law firms and those who are in the highest echelons of practice. It also almost unilaterally focuses on the structural and social impediments within law practice itself. Further, there is little discussion of the problem across international borders, when in fact the problem is global in nature. And finally, it frequently ignores legal education, both in terms of its contribution to the problem and in terms of its potential for enacting solutions. ${ }^{52}$ This essay seeks to expand the pathways to achieve gender equality in law, by broadening the conversation in these critical ways and suggesting further areas of research.

\section{BROADENING THE CONCEPTION OF BARRIERS: BEYOND THE PRACTICE OF BIG LAW}

The research on the barriers that impede women's advancement in law practice has, in recent years, prompted lawyers to promulgate numerous solutions. To give one example,

45 Reichman and Sterling (n 34).

46 Justin D Levinson and Danielle Young, 'Implicit Gender Bias in the Legal Profession: An Empirical Study' (2010) 18 Duke Journal of Law and Policy 1.

47 Joan C Williams, 'Litigating the Glass Ceiling and the Maternal Wall: Using Stereotyping and Cognitive Bias Evidence to Prove Gender Discrimination' (2003) 7 Employee Rights and Employment Policy Journal 287, 288.

48 The term 'double bind' was described in the 1980s by philosopher Marilyn Frye: see The Politics of Reality: Essays in Feminist Theory (Crossing Press, 1983); Kathleen Hall Jamieson, Beyond the Double Bind: Women and Leadership (Oxford University Press, 1997).

49 Deborah L Rhode, 'From Platitudes to Priorities: Diversity and Gender Equity in Law Firm' (2011) 24 Georgetown Journal of Legal Ethics 1041.

50 Jean E Wallace, 'The Benefits of Mentoring for Female Lawyers' (2001) 58 Journal of Vocational Behavior 366.

51 Joan C Williams and Veta T Richardson, 'New Millennium, Same Glass Ceiling? The Impact of Law Firm Compensation Systems on Women', The Project for Attorney Retention, Minority Corporate Counsel Association (2010), 1, 6 .

52 Evan Stark, Coercive Control (Oxford University Press, 2007) 363. 
the Law Society of Upper Canada launched the Justicia Project, a project of first impression in the country, which elicited commitments from medium and large law firms to address gender equality, 'identifying and adopting principles and best practices that promote the retention and advancement of women. ${ }^{53}$ The signatory firms 'signed written commitments to achieve ambitious goals in four core areas: tracking gender demographics, flexible work arrangements, networking and business development and mentoring and leadership skills development for women'. ${ }^{54}$ In the United States, a few years later, a group of women lawyers gathered in Austin, Texas for the inaugural Women's Power Summit on Law \& Leadership. ${ }^{55}$ The Summit convened some of the nation's most prominent women leaders in law and culminated with a blueprint for change, the Austin Manifesto on Women in Law. ${ }^{56}$ Signatories to the Manifesto pledged to take concrete steps to address gender equality in the profession, though the focus was somewhat narrowly tailored to the highest echelons of practice. Large law firms in particular are routinely criticised for their perpetuation of the problems, though this focus tends to ignore the fact that gender inequality spans across all sectors of the profession. These limited examples, while each making important contributions to the movement, are ripe for critique as efforts that involve just a small fraction of the profession as a whole, focusing somewhat singularly on those who practise in the most elite contexts.

The percentage of women who actually practise in large traditional law firms represents only a small sector of the profession. Among all lawyers in the United States, for example, only 9 per cent work in the top 250 firms. ${ }^{57}$ While the exact number of women is unknown, one can extrapolate that it is a relatively small percentage, especially given that women make up only 30 per cent of the legal profession in total. ${ }^{58}$ In fact, the After the JD Study II revealed that women are more likely to be working in the public sector (non-profit or government) than men ( 30 per cent compared to less than 25 per cent, respectively).$^{59}$ In Australia, the percentage is similarly low, with only 5.2 per cent of lawyers working for law firms in the 'Big Six. ${ }^{60}$ Of those who do enter large law firms, about 57 per cent of lawyers leave before their fifth year of practice. ${ }^{61}$ The research on large law firms has become a proxy for law practice generally. This trend is problematic, since in actuality only a small percentage of lawyers generally, and female lawyers specifically, work in this context.

In only limited cases have researchers or scholars pushed beyond this unilateral focus on large law firms to study other sectors of the profession in any meaningful way. ${ }^{62}$ One

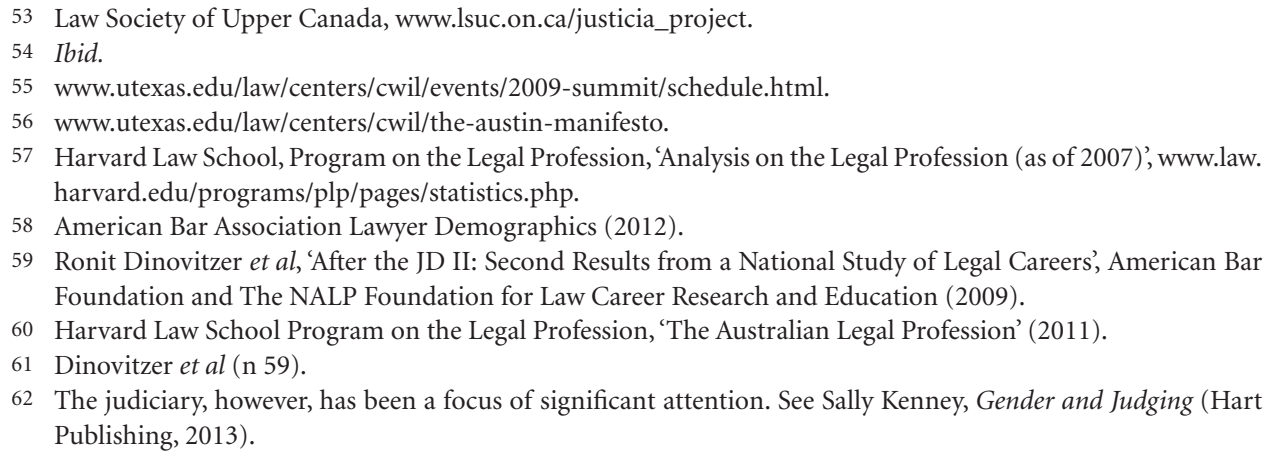


such exception is the work of Eli Wald, who has recently explored the presence of bias and discrimination among in-house legal departments, which are routinely touted as places where women lawyers thrive. ${ }^{63}$ Before Wald's research, there was little evidence to support such claims. Wald addresses and ultimately dispels the myth that in-house legal departments are free of bias and discrimination:

Available evidence suggests that while in-house legal departments feature greater flexibility, diversity, and equality than large law firms and other segments of the legal profession, some of the same patterns that characterize the experience of women lawyers at large law firms and in the legal profession more generally, that is increased participation and representation overall coupled with stratification, under-representation in senior and powerful positions, over-representation in lower-end positions, and pay inequality, also apply to their experience in-house. ${ }^{64}$

Wald's research is incredibly valuable as it provides a counter-narrative to the oft-misinformed belief that corporate law is getting it right. His observations provide further support for the notion that we must actively engage in the study and development of solutions relating to the advancement of women in law in all sectors of the profession. It also follows that many barriers are not in fact unique to law practice at all, but to women generally. Yet, to date, little attention has been paid specifically to any area of practice (aside from the judiciary) outside large law firms. And government and non-profit organisations have not been studied specifically in the context of law; the research that has been done focuses on these areas of employment more broadly. ${ }^{65}$ Given the reality that most lawyers in fact work outside the large law firm context, researchers should follow Wald's lead and explore the position of women in these other realms of the profession. The goal of such an inquiry is twofold: to develop an understanding of the barriers women lawyers face in these other contexts, and to potentially identify solutions based on observations of success.

\section{BROADENING THE CONCEPTION OF BARRIERS: BEYOND LAW-SPECIFIC BARRIERS}

Similarly, the study of barriers impeding women's advancement has been narrowly focused on those that are characteristic of the legal profession itself. The focus on law-specific impediments, while important, ignores the reality that women lawyers do not exist solely in the isolated context of the legal profession; there are in fact significant barriers that exist outside the law — or, stated in another way - there are barriers that are not unique to lawyers, but to all women. In this way, perhaps there is an opportunity to work together with those in other professions, in the academy and more generally.

There are myriad issues confronting women generally that inevitably intersect with those who practise law. The examples explored by Mary Noonan and Mary Corcoran can

63 See Wald (n 34) 75.

64 Ibid.

65 EEOC Women's Work Group Report (2013); see White House Project (n 32). 
be extrapolated to women generally. 'Common reasons women report for leaving the field of law are the lack of flexibility offered by law firms, long hours, child care commitments ... ${ }^{66}$ Low job satisfaction, failure to advance, family dynamics, and lack of power or privilege even in leadership positions are also cited as examples of women's stalled progress. ${ }^{67}$

There are additional barriers that are more general to all women which have not received as much attention. ${ }^{68}$ Although a full investigation is beyond the scope of this paper, my intention is to raise some new areas for exploration that might be useful in understanding and ultimately addressing some of the reasons why women's advancement has in fact stalled. I find particularly compelling the ideas of Evan Stark, who captures the idea of the inter-related nature of the personal and professional: 'Personal life, economic life, and political life are interwoven in so many ways in modern, industrialised societies that it seems eminently reasonable to treat them as part of a single dynamic rather than as separate spheres. ${ }^{69}$ In this way, we should view female attorneys not just in the narrow confines of the law, but more holistically, considering the myriad challenges they face in all facets of their lives that may in fact stand in the way of their advancement.

To give one example that might require further study, the existing discourse has not focused as much on domestic violence. While at first glance it may appear that gender equality in the legal profession and violence against women are unrelated, there is potentially an intersection that has not been sufficiently acknowledged or explored-one that stems primarily from a more broad social patriarchal context. Broadening the conversation to include a more comprehensive understanding of the various factors that may inhibit women's advancement generally is essential and will only better position us to address the problems we observe in the legal profession. Stark articulates this connection: 'Constraining women's liberties in personal life makes them more susceptible to inequalities in the workforce and solidifies heterosexist hierarchies into other public arenas. ${ }^{70}$

Using this example as a point of illustration, I urge a theoretical reframing both of the way in which we conceptualise the barriers and obstacles facing women in law today, and of the way in which we characterise the impact of issues like domestic violence. In the first place, and as an ethical matter, we must acknowledge the breadth of challenges facing women lawyers; it is useful to identify and attempt to ameliorate some of the profession-specific problems, but it is perhaps even more desirable and impactful to frame those problems within a broader context of gender bias and discrimination. Stark explains the connection: 'This new model is rooted in the same tenets that gave birth to the battered women's movement-that the abuse of women in personal life is inextricably bound up with their standing in the larger society and therefore that women's entrapment in their

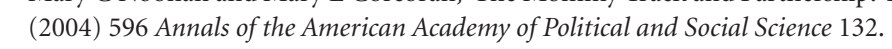

68 There are other barriers that similarly impede women's progress. One example is the impact of addiction on women lawyers. Little research has been done on this topic, though former Michigan State University College of Law student Kathleen Darcy took it up in a recent research paper she wrote for my seminar. Katie Darcy, 'Gender, Leadership and Addiction in the Legal Profession', www.law.msu.edu/king/2012-2013/Darcy.pdf.

69 Stark (n 52) 386.

70 Ibid, 363. 
personal lives can be significantly reduced only if sexual discrimination is addressed simultaneously. ${ }^{\text {,1 }}$ Stark's point, which highlights a cyclical dimension, provides a strong basis for addressing the problem of gender inequality in law as an ethical issue. Taken a step further, when female lawyers are experiencing domestic violence at home, sexual harassment at work, or difficulties finding child care or arranging flexible work schedules, is their work as legal advocates being undermined?

\section{BROADENING THE CONCEPTION OF BARRIERS: BEYOND OUR BORDERS}

The plight of women lawyers and the barriers they face within or outside of the law is not unique to one jurisdiction or country; however, but for the work of a handful of scholars, few have paid attention to or drawn connections surrounding this global inequality. Mary Jane Mossman is one such scholar; her book, The First Women Lawyers, examines the stories of female pioneers in the legal profession and the barriers they encountered in six jurisdictions across the globe. ${ }^{72}$ Mossman '[a]ddresses how their paths crossed, whether literally through the exchange of letters or symbolically as they encountered similar barriers to the profession. ${ }^{73}$ Ulrike Schultz and Gisela Shaw have also contributed both individually and collectively to the field. They are the editors of a one-of-a-kind text, Women in the World's Legal Professions, which attempts to convey the position of women lawyers across borders in contemporary society. ${ }^{74}$ The authors conclude that a project on women's issues in law is problematic because ' $[\mathrm{w}$ ] omen in the various branches of the legal profession do not speak with one voice. ${ }^{75}$ Unlike Schultz, I am not troubled by the difficulty in identifying a singular woman's voice in law and in fact consider the shared experience of women navigating the gendered profession of law to be sufficient as a starting place for dialogue. While I do not assume the existence of a singular profile of a global woman lawyer, in the same way that I would not assume that profile within national borders, there are nonetheless striking similarities among the gendered norms and shared experiences that justify exploration, especially against the backdrop of increasing globalisation of the legal profession. In fact, these shared struggles may well present an opportunity to develop a globalised legal ethics structure.

There is historic support for connections across borders. Women law students who formed the Equity Club at the University of Michigan wrote letters to other students and lawyers in the United States and internationally. ${ }^{76}$ And in the early years of women fighting

71 Ibid, 14 .

72 See Mary Jane Mossman, 'Legal Education as a Strategy for Change in the Legal Profession' in C Brettel Dawson (ed), Women, Law \& Social Change: Core Readings and Current Issues (Captus Press, 2002).

73 Renee Newman Knake, 'The Progress of Women in the Legal Profession' (2009) 29 Pace Law Review 293.

74 Schultz and Shaw (n 4).

75 Ibid.

76 Virginia D Drachman, Women Lawyers and the Origins of Professional Identity in America: The Letters of the Equity Club, 1887-1890 (University of Michigan Press, 1993). 
for access to the legal profession through the court system, there is evidence to suggest that Canadian courts looked to the United States for precedent. As early as 1869 , legal journals in Canada expressed opposition to the admission of women into the profession, referencing the State of Iowa's decision to allow a woman admission to the Iowa Bar. ${ }^{77}$

In June 1869, Arabella Mansfield was admitted to the Iowa bar after passing the bar exam and successfully persuading Justice Francis Springer that an Iowa statute allowing bar admission to 'any white male person, twenty one years of age, who is an inhabitant of this State ... who possesses the requisite learning,' should be deemed gender-neutral in light of a statutory rule of construction. ${ }^{78}$

This phenomenon of glancing across borders for ideas and guidance was also illustrated by Canadian courts referencing the infamous Bradwell $v$ Illinois ${ }^{79}$ decision as a basis for denying women's entry to the profession..$^{80}$ Even today, the two countries at times look to one another when addressing equality in the profession. A recent Canadian Bar Association article highlighted recommendations made by the American Bar Association on diversity in the bench and bar. ${ }^{81}$ The author noted: 'While there are important differences between these countries, this ABA report makes several recommendations to the American legal community that have resonance in the Canadian context. ${ }^{, 82}$

As yet another example, Elizabeth Schneider writes about the growing frequency with which judges consider legal decisions in other countries. 'Courts around the globe are beginning to look beyond their borders in deciding cases, particularly in the area of human rights. ${ }^{83}$ This global attention is not just limited to the courts. Schneider discusses the phenomenon of lawyers from the United States engaging in international legal work, attending human rights conferences, and examining how other countries use international law or international precedents in their local decision-making. ${ }^{84}$ This transnational phenomenon extracted from Schneider's observations and analysis has direct relevance for the global study of women in law. There is benefit to be gained from broadening the movement on women in law to reach beyond our individual borders.

Global perspectives provide cross-country critical insights, experiences and personal affiliations, and offer an opportunity to energise the women's rights movement. They contribute important comparative insights that can change the language, the strategies and advocacy terrain. Especially

77 See Mossman (n 72) 70.

78 Hon Lynne A Battaglia, “'Where is Justice?” An Explanation of Beginnings' (2011) 42 University of Baltimore Law Forum 1.

79 Bradwell v Illinois, 83 US 130 (1872).

80 The Bradwell decision held that the refusal to admit Bradwell to practise law did not violate state law, and that the Supreme Court did not have the authority to enquire into the 'reasonableness or propriety' of state bar admission rules. Ibid.

81 Report of the Canadian Bar Association Task Force on Gender Equality in the Legal Profession, Touchstones for Change: Equality, Diversity \& Accountability (1993).

82 Rebecca Bromwich, 'Innovative Approaches Needed to Address Inequalities in the Legal ProfessionAccording to New ABA Report on Diversity' (Canadian Bar Association, May 2010).

83 Elizabeth M Schneider, 'Transnational Law as a Global Resource: Thoughts on the Case of Women's Rights' (2004) 38 New England Law Review 689.

84 Ibid. 
for younger people, global perspectives may provide a 'transformative' opportunity for women's rights. $^{85}$

Building on these observations, it seems that the issues facing women in the world's legal professions could in fact form the foundation on which to build a global agenda. A conversation that spans the world on the ethical problem of gender inequality in law just might have the 'transformative' potential for change about which Schneider speaks.

\section{BRIDGING THE DIVIDE BETWEEN PRACTICE AND LEGAL EDUCATION}

The insular focus on the practice of law in the context of large law firms and barriers within the borders of specific countries is problematic, but just as a broadening of the conversation is imperative in these contexts, so is it true that there is much to be gained by a broadening of the conversation to include legal education. Kay and Brockman summarise existing efforts in Canada to address gender inequality: 'These measures have included task forces to investigate gender bias in the profession, policy recommendations from the C.B.A., disciplinary rules of professional misconduct, and law society efforts through model personnel and discrimination policies widely distributed to legal practitioners, educational bulletins, and continuing education programs. ${ }^{, 86}$ Missing from this list, and others like it, however, is any reference to or mention of legal education.

Developing effective solutions to the problems facing women attorneys today requires a focus on their root or cause. Cynthia Fuchs Epstein importantly observed that ' $[i]$ nequality in the workplace is created and reinforced by inequality in education. ${ }^{87}$ Just as the problems facing women lawyers have been narrowly construed, so have the solutions; focusing solely on the barriers facing women attorneys in practice is not, on its own, sufficient. Instead, significant attention ought to be directed to the period before lawyers become lawyers, in the early stages of their training, as part of the system of legal education. This approach not only has the potential to be effective, but also, importantly, represents an understanding of the ethical responsibility inherent in the education of future lawyers.

Indeed, law school functions, significantly, as the place where future lawyers first develop impressions about the legal profession. Institutionally, law school plays a critical role in educating future lawyers, most obviously about legal doctrine, jurisprudence and ethics. But despite its essential role in the legal profession, legal education is often considered as a separate entity, and not at all recognised as a critical place for creating change as it relates to the ethical dilemma of gender equality.

It is true that many of the gendered dynamics that plague law firms and corporations are also prevalent in legal education - among students, faculty and administrators. Perhaps not surprisingly, women were absent from law school faculties in the United States

85 Ibid, 689.

86 See Kay and Brockman (n 26).

87 Cynthia Fuchs Epstein, 'Great Divides: The Cultural, Cognitive, and Social Bases of the Global Subordination of Women' (2007) 72 American Sociological Review 1, 9. 
for many years. In 1848, a group of women gathered in Seneca Falls for the first women's rights convention. There, they drafted the Declaration of Sentiments, a list of grievances affecting women of that time. ${ }^{88}$ Many of the grievances, such as the denial of the right to vote, have long since been resolved; the first country to grant women the right to vote was New Zealand, in 1893, followed by countries like Finland in 1906, the United States in 1920, Ireland in 1922, and others following over the next several decades, such as Portugal, which granted it in $1976 .{ }^{89}$ The Declaration of Sentiments noted an absence of women as educators in the fields of theology, medicine and law. ${ }^{90}$ This problem continues to permeate higher education today. Harvard Law School finally hired its first female tenure-system teacher in 1972; between 1972 and 2005, it appointed only 15 tenured total professors to faculty. ${ }^{91}$ Harvard is certainly not alone in its dismal record as it relates to parity among its faculty. Mary Basile identifies the disconnect: 'One would expect a steady increase in the number of women law professors to mirror the achievement of near gender balance in the student population, as law schools graduate a greater number of potential women teachers. However, few schools have been successful in this regard. ${ }^{92}$

Today, although women are found in much greater numbers in legal education, the gender demographics in the legal academy mirror those found in the law firm and corporate worlds. Law school deans and tenured law professors are predominately male, and the culture does not seem to be shifting. Today, in the United States, women account for barely 20 per cent of law school deans and only 28 per cent of tenured law school professors. ${ }^{93}$ Recent research done on gender and law review leadership, a critical part of the pipeline to the job market, reveals a similar disparity, with only about a third of law review editor-in chief positions held by women. ${ }^{94}$ And law review publications., even today, do not include many articles written by women. ${ }^{95}$

In the same way that the legal profession, as an ethical matter, ought to reflect the same gender equality that we use our profession to enforce in other contexts, so must law schools. It seems that the site where we train future lawyers ought, at a minimum, to reflect such equality among its own ranks, and also play an active role in addressing the problem. Yet, there is reason to be concerned that legal education either contributes to the problem, or, put another way, fails to contribute in a meaningful way to the solution. Systemic change requires an examination of the root of any problem. While gender equality in law stems from an embedded cultural sexism, it is also true that legal education might be construed

88 Elizabeth Cady Stanton, The Declaration of Sentiments (1848).

89 Francisco O Ramirez, Yasemin Soysal and Suzanne Shanahan, 'The Changing Logic of Political Citizenship: Cross-National Acquisition of Women's Suffrage Rights, 1890 to 1990' (1997) 62 American Sociological Review 735.

90 Stanton (n 88).

91 Mary Elisabeth Basile, 'False Starts: Harvard Law School's Efforts toward Integrating Women into the Faculty 1928-1981' (2005) 28 Harvard Journal of Law and Gender 143.

92 Ibid, 191.

93 American Bar Association, Law School Staff by Gender and Ethnicity (5 May 2009), www.abanet.org/legaled/ statistics/charts/facultyinformationbygender.pdf.

94 'Ms JD', Women on Law Review: A Gender Diversity Report (2009).

95 Jennifer C Mullins and Nancy Leong, 'The Persistent Gender Disparity in Student Note Publications' (2011) 23(2) Yale Journal of Law \& Feminism 385. 
as a root of the problem. In her pivotal work on the undertraining of female law students, Irene Ayers explains that ' $[1]$ ittle if any attention is paid to how the earlier training that these attorneys received in law school might have contributed to the later career obstacles they face. ${ }^{96}$

Yet, despite Ayers' identification of this omission in legal education, the idea has had little traction in the literature and in practice. Lani Guinier in many ways pioneered this all-important conversation with her groundbreaking study of law students at the University of Pennsylvania Law School. ${ }^{97}$ A few legal scholars have followed Guinier's lead and further delved into this issue, as relates to both students and faculty. ${ }^{98}$ Deborah Rhode, addressing the 2002 Conference on Legal Ethics, called for various segments of the legal profession to come together to develop solutions to the ongoing problems of inequality. She remarked: 'More bridges between the bench, bar and the academy could help keep these issues central to bar reform agendas. ${ }^{99}$ Mary Jane Mossman has also called for increased attention to law school as a site for work on equality and the profession:

[I]t is altogether obvious that in the legal system, as in the social world, change will not come from the mountain top but rather from earthworming: the preparation of the soil by individuals who are prepared to challenge the mainstream, not just in forging a critical law school curriculum but also in working to challenge the dominant paradigms of legal work within the profession. ${ }^{100}$

Although there exists an inherent, often profound disconnect between law school and the profession, a full exploration of which is beyond the scope of this essay, some law schools have in fact responded swiftly to the idea that our legal marketplace is radically changing in the current economic climate and that law practice will soon not look as it does now. ${ }^{101}$ 'Whether consciously or not, in order to survive, many lawyers are widening their range of skills, broadening their sphere of impact, and are anxious that the world does not pigeonhole them as detached scribes who sit in ivory towers. Many lawyers, in other words, can no longer eke a living from the law alone.' ${ }^{102}$ Fewer law graduates are choosing to practise in large firms in the first place, or, if they do, they are using such roles as a bridge to another area of law. Law schools are responding by developing innovations in their curriculum to best prepare their students to succeed in this new era. ${ }^{103}$ If these institutions can tailor their

96 Irene Segal Ayers, 'The Undertraining of Lawyers and its Effect on the Advancement of Women and Minorities in the Legal Profession' [2009] Duke Forum for Law \& Social Change 72.

97 Lani Guinier, 'Becoming Gentlemen: Women’s Experiences at One Ivy League Law School' (1994) 143 University of Pennsylvania Law Review 1.

98 See Ayers (n 96); Abigail A Rury, 'The Pipeline to the Legal Profession: Perspectives from Michigan State University College of Law' [2012] Michigan State Law Review 1717; Elizabeth Mertz et al, After Tenure: PostTenure Law Professors in the United States (American Bar Foundation, 2011).

99 Deborah L Rhode, 'Gender and the Profession: The No-Problem Problem' (2002) 30(3) Hofstra Law Review 1011.

100 Mossman (n 72) 621.

101 Richard Susskind, The End of Lawyers? Rethinking the Nature of Legal Services (Oxford University Press, 2010).

$102 \mathrm{Ibid}, 6$.

103 To give one example, Stanford Law School's Program in Law, Science, and Technology takes advantage of the school's location in Silicon Valley to assist businesses with complex intellectual property issues and promote informed public policies on science and technology. See https://www.law.stanford.edu/organizations/ 
curricula by training law students to navigate the profession through the changing institutional dynamics, they should also be able to address the gendered barriers that students have faced for decades. In fact, there may well be a relationship between the changing legal market and the experiences of women lawyers, or the decision of women to even attend law school in the first place, that is worthy of further study.

There is a significant ethical responsibility on the part of law schools not just to educate their students in doctrinal legal subjects but to equip them with the tools they need to succeed in a profession marked by significant gender bias. As a starting point, ought law schools not serve as a model of the profession more broadly by including women among their tenured faculty and administration in a more representative way? This argument for greater representation is multifaceted and has at its core a sense of ethics as it relates to the responsibility law schools have to shape the future of the profession. In discussing the 'special contributions' ${ }^{104}$ made by female professors to the legal academy, Mary Basile says: 'Studies indicate that the "vestiges of sexism" appear to be less pronounced at law schools with more women faculty.' ${ }^{105}$ She attributes this phenomenon to a number of factors, including 'expansion of the spectrum of viewpoints, heightened sensitivity to issues disproportionately affecting women, and the presence of female role models for women students. ${ }^{\prime 06}$ Basile's research provides strong support for the addition of women.

Legal education is in fact an ideal site at which to address gender inequality in two specific ways. First, as just discussed, law schools should strive to be emblematic of equality in law. Second, beyond projecting a more balanced vision of what the profession ought to look like, law schools should take specific concrete steps, such as creating curricular initiatives that will not only educate students about inequality in law, but also provide them with necessary skills that will increase the likelihood of their success in the growing global profession.

Today, leaders of law schools, including deans ${ }^{107}$ and tenured professors, ${ }^{108}$ editors of law reviews ${ }^{109}$ and leaders of student organisations ${ }^{110}$ are predominately male, mirroring the power imbalance that plagues the profession generally. Not only does this result in a skewed vision of what the profession should look like, but it conveys sets of problematic messages to students as we prepare them for legal practice. As Deborah Rhode explains, 'those of us who teach and write about the legal profession need to make the unfinished

programs-and-centers/stanford-program-in-law-science-technology. Miami Law School's LawWithoutWalls program teams its students up with other law and business students from around the world to develop business plans that address the economic, technological and globalisation factors that are changing the legal market. See www.lawwithoutwalls.org/about.

104 See Basile (n 91) 189.

105 Ibid.

106 Ibid.

107 Association of American Law Schools, 2008-2009 AALS Statistical Report on Law Faculty (2009). See also American Bar Association, Law School Staff by Gender \& Ethnicity (2009).

108 See Mertz et al (n 98) 15, 46.

109 'Ms JD' (n 94).

110 Heather Johnson, 'Perpetuating Bias: The Gendered Culture of Law Student Leadership', unpublished paper on file with author. 
agenda of equal opportunity part of our agenda. Many students are surprisingly clueless about the extent of gender inequality and the factors that perpetuate it.'111

It is also worth noting that the numbers alone do not tell the entire story. Tenured women also experience gendered difference in their professional lives. For example, according to one study, they are less likely to feel respected by their colleagues or that they are listened to with respect to hiring and promotion decisions. ${ }^{112}$ Echoing the arguments made by Fiona Cownie, I suggest that the ongoing study of female legal academics is essential. It has the potential not just to change the dynamics of the legal academy, but also to change the broader institution of higher education, and the legal profession itself. Cownie writes: 'The behavior, attitudes, and values of legal academics have implications for the future development of the discipline of law. ${ }^{113}$

The second dynamic - that law schools in fact have an ethical responsibility to educate their students in a way that allows them to successfully navigate (and arguably change) the gendered landscape-is being addressed, albeit in limited ways, as several of us in the academy have implemented programs and initiatives to help our students gain critical skills and information to navigate the profession. Such efforts are not necessarily new.

Historically, various efforts have been made to incorporate a focus on gender in the curriculum. The earliest curricular initiative was implemented in 1969 with the introduction of a Women and the Law course at New York University. ${ }^{114}$ While other schools began offering similar courses in the early 1970s in addition to engaging in other initiatives, such as the conference spearheaded by Ruth Bader Ginsberg in 1972 entitled 'The Law School Curriculum and the Legal Rights of Women', there has been a universal failure to mainstream the teaching of gender across the law school curriculum. ${ }^{115}$

There is no empirical data available on the number of similar courses offered today, or on enrolment in such courses, though the figures are certainly higher than they were in the 1970s. But beyond the courses that may exist, it is nonetheless true that there are only a handful of examples of law schools that have implemented any comprehensive initiatives, curricular or otherwise, designed to address some of the gendered challenges students will encounter in the profession.

To give one example, at the University of Maryland, Paula Monopoli created the Women, Law and Equality program. The first initiative of its kind, it

provides an opportunity for students to engage in critical thinking about cutting-edge issues in gender and leadership. It seeks to produce lawyers, both male and female, who are aware of the barriers that face women seeking positions of leadership in society and who will actively promote women in these roles. ${ }^{116}$

111 See Rhode (n 99) 1001.

112 See Mertz et al (n 98) 47-48, 56-57.

113 Fiona Cownie, 'Women Legal Academics: A New Research Agenda' (1998) 25 Journal of Law \& Society 102, 103.

114 Martha Craig Daughtrey, 'Women and the Constitution: Where We Are at the End of the Century' (2000) 75 New York University Law Review 1.

115 Grace Ganz Blumberg, 'Women and the Law: Taking Stock after Twenty-Five Years' (1996) 6 ULCA Women's Law Journal 279.

116 www.law.umaryland.edu/programs/wle. 
Monopoli's program comprises a combination of a classroom experience (inclusive of theoretical study) and an experiential component that allows students to gain exposure to the practice of law. Joan Williams runs the Center for WorkLife Law at Hastings Law School, which engages in cutting-edge research on issues related to the intersections of gender, work, discrimination, and leadership. The Center for Women in Law at the University of Texas periodically hosts a one-day 'Leadership Boot Camp' for female law students and recent graduates. Further efforts are being made across the globe, albeit in limited contexts. The Southeast European Law School Network hosted a conference in 2012, 'Legal Perspectives of Gender Equality in South East Europe', which included a focus on gender equality in legal education. ${ }^{117}$ Other European institutions, such as the University of Kent Law School, have established gender centres devoted to gender-based research.

At Michigan State University College of Law, I implemented a two-pronged approach that began with the creation of two seminars as part of the upper-level elective curriculum: Gender, Power, Law \& Leadership and Global Perspectives on Women in Law. The former was inspired by the glaring omission of women from positions of power and leadership in the legal profession and beyond, exposing students to various theories of leadership and pursuing an inquiry into how leadership intersects with gender, power and law. The latter provides students with exposure to women's experiences in the world's legal professions.

One of the critical features of these courses is the requirement that students select and read a biography about a transformative woman lawyer, which they later share with the class. The history of women's advancement in the legal profession is better appreciated through individual stories and personal narratives. ${ }^{118}$ Such an approach is supported by Fiona Cownie's conclusion that '[s]tudying women legal academics may contribute not only to our knowledge of the university as an institution, but also to our knowledge of the discipline of law. ${ }^{119}$ The stories of the pioneering women who transcended the domestic sphere and entered the practice of law are intriguing to contemporary women lawyers; they are captivated by the experiences of these women, particularly those who achieved notable 'firsts.' ${ }^{120}$ Cynthia Grant Bowman explains that this fascination is driven by a number of factors, including the inspiration gained by reading about powerful struggles and obstacles overcome: 'We see their imperfections, their emotions, and their struggles, which are often eerily similar to our own.' ${ }^{\text {,1 }}$ She further explains that women today feel a profound sense of empathy for the struggles endured by these women, and at the same time can take away a lesson that while the struggle that follows will be difficult, there are real examples of women who have figured out how to achieve personal fulfilment and professional success. ${ }^{122}$ These are important messages to convey to our students. Storytelling also serves as a mechanism

\footnotetext{
117 www.seelawschool.org.

118 Mary Jane Mossman, The First Women Lawyers: A Comparative Study of Gender, Law \& the Legal Profession (Hart Publishing, 2006).

119 See Cownie (n 113) 109.

120 Carol Sanger, 'Curriculum Vitae (Feminae): Biography and Early American Women Lawyers' (1994) 46 Stanford Law Review 1245. See also Cynthia Grant Bowman, 'Bibliographical Essay: Women and the Legal Profession' (1999) 7 American University Journal of Gender, Social Policy and the Law 149.

121 Bowman (n 120).

122 Ibid.
} 
to counter some of the essentialist dangers inherent in a focus on 'women's' experience. ${ }^{123}$ These lived experiences and anecdotes of women lawyers have the potential to form the backdrop of a global conversation on gender equality in law.

From these two seminars evolved an extra-curricular initiative, the Women in Law Leadership Council (WLLC). ${ }^{124}$ Compelled by their study of the profession both in the United States and across the globe, several students identified an unmet need to better prepare female students for the gendered profession of which they would soon be a part that expanded beyond the classroom, and we worked collaboratively to create a project that would serve this end. Although an extensive discussion of the project's specifics is beyond the scope of this essay, its mission statement is illustrative: '[T]he WLLC facilitates the opportunity for female law students to identify challenges faced in law school and the legal profession, provides a forum for students to interact and network with female faculty, lawyers, and other students, and empowers female student leaders with the skills and resources to survive and thrive in their future legal careers.'125

These few examples, while perhaps compelling in their own right, nonetheless illustrate the dearth of formal programs designed to address gender inequality in law schools. It is therefore time to take stock of the role of legal education in preparing students for practice, particularly in this changing legal climate, and study the potential for and developing more substantial linkages between practice and education.

\section{CONCLUSION}

Over the past few decades, significant attention has been devoted to addressing ongoing and pervasive gender inequality in law. The problem, though profound, has not largely been viewed as one central to the profession, and the hypocrisy that stems from the devotion to the preservation of rights and equality while maintaining a sexist status quo has not been illuminated. While it is true that some progress has been made in the identification of barriers and the promulgation of solutions, the significantly gendered dynamics persist. This essay offers an ethics framework in which to situate this inequality, and urges further conceptualisation of the problem along new pathways.

123 Cynthia Grant Bowman, 'Women in the Legal Profession from the 1920s to the 1970s: What Can we Learn from their Experience about Law and Social Change?' (2009) 61 Maine Law Review 1.

124 The WLLC was initially inspired by MSU law students Heather Johnson and Courtney Gabbara; their leadership was subsequently followed by Kathleen Hennessey and Elise Elzinga. The project's success was elevated due to the role of Law College Dean Joan Howarth, who was deeply involved in the project.

125 On file with author. 